ISA

Arboriculture \& Urban Forestry 2016. 42(5): 329-345

\title{
Carbon Uptake and Air Pollution Mitigation of Different Evergreen Shrub Species
}

\author{
Jacopo Mori, Alessio Fini, Gianluca Burchi, and Francesco Ferrini
}

\begin{abstract}
Three independent experiments assessed $\mathrm{CO}_{2}$ assimilation and metals leaf deposition of seven evergreen shrub species (Arbutus unedo L., Elaeagnus $\times$ ebbingei L., Laurus nobilis L., Ligustrum japonicum Thunb., Photinia $\times$ fraseri Dress., Viburnum tinus subsp. lucidum L., and Viburnum tinus subsp. tinus L.). $\mathrm{CO}_{2}$ assimilation and carbon allocation were determined in 2011 (Exp. 1) under optimal water availability and in 2012 (Exp. 2) under drought on potted plants. A third experiment (Exp. 3) measured seasonal leaf depositions of $\mathrm{Cd}, \mathrm{Cu}, \mathrm{Ni}, \mathrm{Pb}$, and $\mathrm{Zn}$ in 2011 on plants transplanted in proximity of a four-lane road.

E. $\times$ ebbingei showed the highest $\mathrm{CO}_{2}$ assimilation under optimal water availability but one of the lowest under drought (Exp. 1, 2). Conversely, $P . \times$ fraseri had intermediate $\mathrm{CO}_{2}$ assimilation but it declined less during drought compared to the other species. In Experiment 3, E. $\times$ ebbingei showed the highest metal deposition, mainly due to its greater leaf area. Greater rainfall and $\mathrm{RH} \%$ decreased metal depositions, whilst greater wind velocity and air temperature increased leaf depositions. Species which drastically reduce $\mathrm{CO}_{2}$ assimilation under drought ( $V$. tinus subsp. lucidum, L. japonicum, E. $\times$ ebbingei) are not recommended in droughtprone environments, where drought-tolerant "mesic" species $(P . \times$ fraseri), should be preferred. E. $\times$ ebbingei could be used to optimize deposition of metals. The three experiments provide useful insights especially about $\mathrm{CO}_{2}$ assimilation (Exp. 1, 2) and air pollution mitigation (Exp. 3) of widely used shrubs for application in urban areas and planning of roadside greening in southern Europe.

Key Words. Arbutus unedo L.; $\mathrm{CO}_{2}$ Assimilation; Drought; Elaeagnus $\times$ ebbingei L.; Italy; Laurus nobilis L.; Leaf Deposition; Ligustrum japonicum Thunb.; Meteorological Parameters; Photinia $\times$ fraseri Dress.; Relative Growth Rate; Seasonal Trend; Shrub; Trace Metals; Traffic Pollution; Viburnum tinus subsp. lucidum L.; Viburnum tinus subsp. tinus L.
\end{abstract}

Human activities, such as vehicle traffic, industry, and the heating and conditioning of buildings, contribute to changing the atmospheric environment in terms of $\mathrm{CO}_{2}$ and air pollution concentrations (Grubler 1994; O’Meara 1999; Suzuki 2006). Since the early 1900s, the average surface temperature of Earth has increased by $0.74^{\circ} \mathrm{C}$ (IPCC 2013). Global warming is mainly driven by $\mathrm{CO}_{2}$, which is largely emitted from the combustion of fossil fuels (PBL Netherlands Environmental Assessment Agency 2013). Urban greening has been reported to contribute effectively to the uptake and storage of atmospheric $\mathrm{CO}_{2}$ through its conversion into organic carbon mean photosynthesis. $\mathrm{CO}_{2}$ is then stored as woody biomass for medium to long periods, depending on the average life span of the species involved and the use of the woody material after removal from the planting site (Pugh et al. 2012; Nowak et al. 2013). The potential of trees and shrubs to remove $\mathrm{CO}_{2}$ and pollutants is enhanced when they are planted within or near urban environments, where the concentration of $\mathrm{CO}_{2}$ and pollutants is higher (Niinemets and Peñuelas 2007). In addition, they offer others benefits in situ, such as improving microclimate conditions and reducing energy consumption of buildings for air conditioning (McCarthy et al. 2010). Plant species differ in their relative capacity to assimilate and store $\mathrm{CO}_{2}$ (Somogyi et al. 2008; Semwal et al. 2013). Previous research investigated $\mathrm{CO}_{2}$ storage by several trees species and found that this is positively related to life span and size at maturity of the tree (Nowak and Crane 2002). However, $\mathrm{CO}_{2}$ storage potential of shrubs has been poorly investigated, even though they may account for about $10 \%-11 \%$ of total carbon storage and for $21 \%-25 \%$ of total annual carbon uptake by urban vegetation (Jo and McPherson 1995). 
In Mediterranean areas, the use of droughttolerant shrubs can considerably increase carbon sequestration by local vegetation (Bombelli and Gratani, 2003). Unfortunately, the degree of drought tolerance and the mechanisms adopted to cope with drought have not been studied for most shrub species commonly planted in the urban environment. Particular interest should be given to determining which species are capable of tolerating (rather than avoiding) drought, thus maintaining high $\mathrm{CO}_{2}$ assimilation during dry periods (Bussotti et al. 2013; Fini et al. 2014). Shrub species are suggested as valid complements, especially where there is not enough space for tree growth or where local legislation imposes specific distances for tree plantation along streets or buildings.

In parallel with $\mathrm{CO}_{2}$ assimilation and carbon storage, plants may play a role in decreasing local air pollution. Particulate matter (PM) is the principal component of anthropogenic air pollutants. PM includes a mixture of elements, heavy metals, black carbon, polycyclic aromatic hydrocarbons, and other substances suspended in the atmosphere (Bell et al. 2011). Plants can adsorb and absorb PM, as well as other noxious gaseous pollutants such as $\mathrm{So}_{\mathrm{x}}, \mathrm{NO}_{\mathrm{x}}$, and $\mathrm{O}_{3}$ (Nowak et al. 2000; Nowak et al. 2006; Bealey et al. 2007), and pollution-capturing efficiency is speciesspecific (Dzierzanowski et al. 2011; Sæbø et al. 2012; Mori et al. 2015a). Generally, it has been found that coniferous species intercept higher amounts of particulates due to their complex leaf structures compared to broad-leaved species (Beckett et al. 2000; Freer-Smith et al. 2005). In addition, evergreen plants are able to intercept air pollutants during winter as well (Freer-Smith et al. 2005), when the concentration of air pollutants is usually higher (Pikridas et al. 2013). Species with large leaf areas and dense canopies can create higher air turbulence and consequently have a higher impaction of suspended particles compared to species with low-dense canopies (Mori et al. 2015b). Trees can also act negatively, increasing air pollution concentrations at the pedestrian level by reducing air circulation (Buccolieri et al. 2009; Salmond et al. 2013).

Leaf anatomical and ultrastructural traits, such as texture, surface roughness, presence of pubescence, and the quantity and size of stomata are positively related to the retention capacity of leaves toward PM (Huixia et al. 2013). Leaf surfaces are temporary retention sites for pollutants, the presence of which is influenced by meteorological factors (Nowak et al. 2006). Thus, an interesting aspect of the interaction between plants and air pollutants is how deposition of pollutants on leaves changes over time. For example, Anicic et al. (2011) found a seasonal accumulation, from May to September, of Cr, Fe, Ni, Zn, and $\mathrm{Pb}$ on leaves of Aesculus hippocastanum and Tilia spp., but similar information about shrub species in dry and warm climates is still lacking. Indeed, most of the research in the last 15 years has been carried out on temperate tree species (Beckett et al. 2000; Nowak et al. 2002; Nowak and Crane 2002; Pugh et al. 2012). Elevated concentrations of heavy metals are common in urban areas as a result of both a wide range of human activities and natural processes (Lu et al. 2010).

As heavy metals are strongly associated with PM (Duzgoren-Aydin et al. 2006), especially with the coarse fraction having diameters up to $10 \mu \mathrm{m}\left(\mathrm{PM}_{10}\right)$ (Araujo and $\mathrm{Nel} 2009$ ), several studies have measured some heavy metals as descriptors of air pollutants (Fowler et al. 2003; Mori et al. 2015a). To improve knowledge of the benefits of shrubs for urban landscape, three experiments were carried out to characterize the following seven shrub species regarding their capacity for $\mathrm{CO}_{2}$ uptake and storage and air pollution sequestration: Viburnum tinus subsp. lucidum L. cited as Viburnum lucidum, Viburnum tinus subsp. tinus L. cited as Viburnum tinus, Arbutus unedo L., Photinia $\times$ fraseri Dress., Laurus nobilis L., Elaeagnus $\times$ ebbingei L., and Ligustrum japonicum Thunb. $\mathrm{CO}_{2}$ uptake and storage were evaluated under conditions of non-limiting moisture availability (Exp. 1) and drought stress (Exp. 2), while a third experiment (Exp. 3) aimed to identify the species with highest leaf deposition of trace metals ( $\mathrm{Cd}, \mathrm{Cu}, \mathrm{Ni}, \mathrm{Pb}$, and $\mathrm{Zn}$ ) (Viburnum tinus was not included in this experiment), to study the relationships between trace metal depositions trends and meteorological parameters, and to identify the possible sources responsible for the presence of metals on leaves. 


\section{MATERIALS AND METHODS}

\section{Experiment 1: Carbon Uptake and Storage Under Optimal Water Avail- ability}

In autumn 2010, 84 uniform, two-year-old shrubs (12 per species) of Arbutus unedo, Elaeagnus $\times$ ebbingei, Laurus nobilis, Ligustrum japonicum, Photinia $\times$ fraseri, Viburnum lucidum, and Viburnum tinus, were potted in 3L containers. The substrate was a peat:pumice mixture $4: 1,(\mathrm{v} / \mathrm{v})$, added with $3 \mathrm{~kg} \mathrm{~m}^{-3}$ of a controlled release fertilizer (Osmocote Exact, 18-2,5-7, 8-9 months, Everris, Intl. B.B, Geldermalsen, The Netherlands). Shrubs were arranged in a randomized block design, with six blocks of two shrubs per species in each block, and grown outside in Sesto Fiorentino (43.816652 N, 11.199673 E), Florence, Italy, under full sunlight. Average maximum temperature of the area from 01 June to 01 September, calculated over the last 30 years, is $30.2^{\circ} \mathrm{C}$ with peaks of $42^{\circ} \mathrm{C}$. The average rainfall (June to September for the same period) is $149.8 \mathrm{~mm}$ (Wikipedia 2016).

Shrubs were irrigated daily to container capacity to avoid water stress for the entire experimental period.

Daily trends of net photosynthesis and transpiration were measured for 12 consecutive days during summer 2011, from 9:00 am to 6:30 pm, using an infrared gas analyzer (Ciras 2, PP-system, Amesbury, Massachusetts, U.S.). Measurements were conducted at $380 \mathrm{ppm}$ of $\mathrm{CO}_{2}$ and ambient irradiance on 18 current-season, fully expanded leaves per species. Water use efficiency (WUE, $\mu \mathrm{mol} \mathrm{CO}_{2} /$ mmol $\mathrm{H}_{2} \mathrm{O}$ ) was calculated as the ratio between $\mathrm{CO}_{2}$ assimilation and transpiration for all 12 days of measurement (Gebhardt el al. 2014). Mean daily assimilated $\mathrm{CO}_{2}$ per unit leaf area was obtained applying integral analysis of the daily $\mathrm{CO}_{2}$ assimilation curve as reported by Fini et al. (2012). In detail, total assimilated $\mathrm{CO}_{2}$ was estimated by plotting the mean daily net $\mathrm{CO}_{2}$ assimilation versus time and, thereafter, applying an integral analysis to calculate the area underlying the curve. To obtain daily $\mathrm{CO}_{2}$ assimilation per plant, the mean $\mathrm{CO}_{2}$ assimilation per unit leaf area of each species was multiplied per the total leaf area of shrubs, assuming that self-shading was not relevant because of the small size of the shrubs.

Biomass measurements were carried out at the beginning and at the end of the experiment on four shrubs per species. In November 2011, shrubs were cut off at the root flare and roots were cleaned from the medium using an air flush. All leaves were separated from stems and immediately scanned with an A3 scanner. An image analysis software (Image Tool 1.3, UTHSCSA) was then used to measure leaf area. To determine dry weight, leaves, stems, and roots were oven dried at $70^{\circ} \mathrm{C}$ until constant weight was reached $(\approx 72$ hours). Root-to-shoot ratio was calculated as the ratio between root dry weight and leaves + stem dry weight (Fini et al. 2011). Biomass allocation (\%) was calculated as the change in dry mass of a specific plant organ (stems, roots, and leaves) over the change in dry mass of the whole plant (stems + leaves + roots) with the aim of identifying the species that allocated and stored more carbon into more durable organs compared to leaves.

\section{Experiment 2: Carbon Uptake Under Drought Stress}

In October 2011, 144 three-year-old shrubs of the same species used in Experiment 1 (24 shrubs per species; Laurus nobilis was not used), were potted in 5L containers. Experimental site, substrate, and fertilization were the same as in Experiment 1, but a novofol foil (see Fini et al. 2012) was used to protect shrubs from undesired rainfall. Shrubs were arranged in a randomized block design of three blocks with eight shrubs per species in each block. Container capacity, wilting point, and waterholding capacity of the substrate were determined using a gravimetric method (Sammons and Struve 2008) as described in other works (Fini et al. 2011; Fini et al. 2013). All shrubs were watered daily to container capacity (CC) until August, and then exposed to water stress according to the following treatments: 1) WW, 72 shrubs (four shrubs per species per block) were watered daily to container capacity throughout the experiment; and 2) WS, (72 shrubs), water withheld from four shrubs per species for two periods of five days each (drought phase 1 and 2), separated by 14 days of partial relief. During partial relief the substrate moisture was maintained at $30 \%$ of CC, corresponding to mild to moderate drought (Ruiz-Sanchez et al. 2000; Fini et al. 2011) (Figure 4A). Physiological parameters were measured six times during the 24 days of the water stress experiment according to the following plan: 
1) leaf gas exchange $\left[\mathrm{CO}_{2}\right.$ assimilation (A); traspiration $(\mathrm{E})$; water use efficiency $(\mathrm{WUE}=\mathrm{A} / \mathrm{E})]$ were measured at T-0 (before the onset of drought), T-1 (one day after imposition of drought), T-2 (three days after imposition of drought), T-3 (five days after imposition of drought), T-4 (end of partial relief), T-5 (end of experiment), using the same methods and instruments as described in Experiment 1;

2) pre-dawn water potential was measured at T-3 using a Scholander type pressure bomb (PMS Instruments, Albany, Oregon, U.S.) between 3:00 and 5:00 am on four leaves per species, treatment, and block;

3) maximum quantum yield of PSII photochemistry $(\mathrm{Fv} / \mathrm{Fm})$ and chlorophyll a fluorescence induction (OJIP) curve were performed with HANDY PEA (Hansatech Instruments Ltd, Norfolk, United Kingdom) on four leaves per species, treatment, and block (44 leaves in total);

4) drought-induced changes in growth rate were measured calculating the relative growth rate (RGR) of each species from the beginning to the end of the experiment, as described in a previous work (Fini et al. 2010).

\section{Experiment 3: Leaf Surface Accumu- lation of Trace Metals}

In spring 2010, 50 three-year-old shrubs of $A$. unedo, E. $\times$ ebbingei, L. nobilis, L. japonicum, P. $\times$ fraseri, and $V$. lucidum (300 shrubs in total) were planted in a field next to a high-traffic road. Before planting, soil was plowed to $40 \mathrm{~cm}$. Shrubs were planted into hand-dug planting holes (as deep as the rootball and 1.5 times the width of the rootball) and irrigated as required to avoid any drought stress during the first year. Shrubs were planted to form two vegetation belts, each $30 \mathrm{~m}$ long and $5 \mathrm{~m}$ wide. These belts were parallel to a four-lane road (average daily number of vehicles was 12,000) in Pescia, Italy (N 4352'57.7992", E $\left.10^{\circ} 40^{\prime} 58.0692^{\prime \prime}\right)$, and were at a distance of $1.5 \mathrm{~m}$ from the road verge. Distance between belts was $30 \mathrm{~m}$. Twenty-five shrubs per species formed a $5 \mathrm{~m}$ $\times 5 \mathrm{~m}$ section in each belt. The experimental area is located $35 \mathrm{~km}$ from the Ligurian Sea and the land is dedicated mainly to floricultural and residential uses (Figure 1). Climate parameters for the area during the experiment are reported in Table 1. The dominant wind in the experimental plot is from the sea (west to east), thus the barriers are on the leeward side of the road (Figure 1). At planting, shrubs were pruned to uniform size of $150 \mathrm{~cm}$, with the exception of L. japonicum and E. $\times e b b$ ingei which were $130 \mathrm{~cm}$ tall. Initial total leaf area was measured on four shrubs per species. To measure leaf area, shrubs were fully defoliated and leaf fresh weight was immediately determined; $30 \%$ (in weight) of the leaves of each shrub were subsampled and used for the leaf area measurements, which were carried out using a RS2XA illumination and camera system (Kaiser, Germany) and A3 Lightbox (G.C.L., Durham, UK) with WinDIAS software (Dynamax Inc., Houston, Texas, U.S.). Each subsample (30\% in weight) was then dried separately and the specific leaf area (SLA) was calculated on those leaves as the ratio between their area and dry weight. SLA values were then multiplied per the total leaf dry weight of samples to obtain the total leaf area of each plant (Table 2).

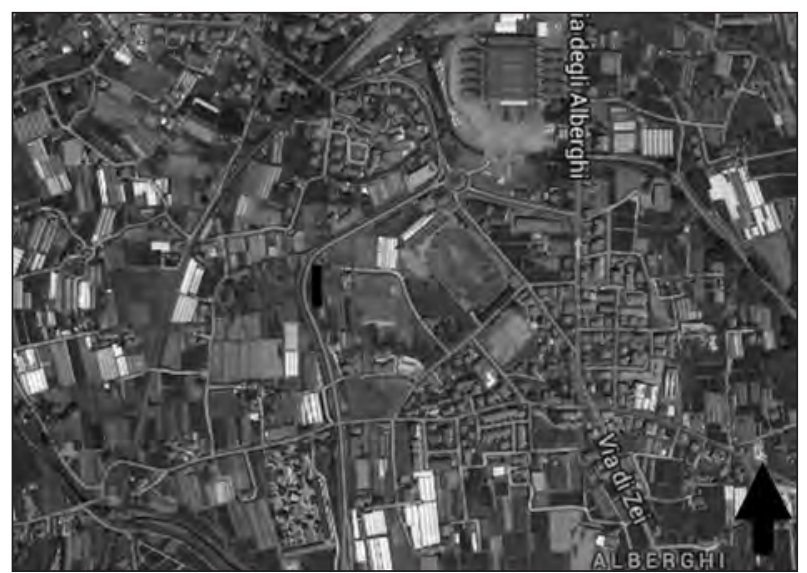

Figure 1. Arial photo of the area surrounding the experimental site. The orientation of the two vegetation belts (indicated with dark rectangle) and the main land use areas (agricultural and residential) are shown. Black arrow indicates north.

Table 1. Meteorological data for the experimental area of the three periods prior to the 2011 samplings.

\begin{tabular}{lccr}
\hline Sampling periods & 19 May - 21 June & 21 June - 03 August & 03 August - 04 October \\
\hline Precipitation $(\mathrm{mm})$ & 10.80 & 11.20 & 80,00 \\
Wind direction & SW & SW & WSW \\
Wind speed $\left(\mathrm{m} \mathrm{s}^{-1}\right)$ & 0.80 & 0.80 & 0.62 \\
Temperature $\left({ }^{\circ} \mathrm{C}\right)$ & 20.78 & 23.33 & 23.24 \\
Relative humidity $(\mathrm{RH} \%)$ & 71.45 & 63.94 & 61.33 \\
\hline
\end{tabular}


Table 2. Leaf area $\left(\mathrm{m}^{2}\right)$ of the six shrub species used for trace metals analysis at planting date (autumn 2010).

\begin{tabular}{lll}
\hline & Mean & SD \\
\hline Viburnum lucidum & 0.41 & 0.04 \\
Arbutus unedo & 0.30 & 0.01 \\
Photinia $\times$ fraseri & 0.35 & 0.05 \\
Laurus nobilis & 0.44 & 0.09 \\
Elaeagnus $\times$ ebbingei & 0.50 & 0.06 \\
Ligustrum japonicum & 0.20 & 0.05 \\
\hline
\end{tabular}

In 2011, leaf trace metal deposition was measured three times (June, August, and October) on leaves formed in the current growing season in order to avoid any confusing age-related effects. Samplings were conducted after at least 10 rainless days. Two replicates of 10 fully expanded leaves per species per belt (40 leaves in total) were collected, including leaves at different heights. The leaf area of every sample was measured. Healthy leaves of each species were collected at a distance of at least $1.5 \mathrm{~m}$ from the adjacent species in order to reduce the influence of position. During the experiment, 72 samples were collected and immediately taken to the laboratory for subsequent analysis. In the laboratory, leaves were washed in $50 \mathrm{ml}$ of a solution composed of distilled water and $\mathrm{HCl}$ $0.01 \mathrm{M}$ ( $\mathrm{pH} 2.0$ ), per 30 minutes, placing samples on an orbital shaker. The concentrations of $\mathrm{Zn}$, $\mathrm{Cd}, \mathrm{Pb}, \mathrm{Ni}$, and $\mathrm{Cu}$ in the solutions of the different samples were directly analyzed by Inductively Coupled Plasma - Optical Emission Spectrometer - Dual Vision (Optima 2000, Perkin Elmer, Waltham, Massachusetts, U.S.). The results were expressed as weight of metals per unit of leaf area.

To measure the quantity of metals washed off from the canopy by precipitations, two containers $(50 \mathrm{~cm} \times 100 \mathrm{~cm})$ were placed at the base of four replicate shrubs of each species. Control containers were placed at the same distance from the street in an area without vegetation. Rainwater in the containers was collected, measured, and stored in the dark at $0^{\circ} \mathrm{C}$ from June to October 2011, after each significant rain event ( $>5 \mathrm{~mm}$ ). In November 2011, each rainwater sample was mixed until complete re-suspension of the sediments was reached and greater homogeneity within the sample was obtained; $20 \mathrm{ml}$ of each sample was collected and fully evaporated at $50^{\circ} \mathrm{C}$ to collect the dry matter. The dry matter was then digested with $5 \mathrm{ml}$ of a mixture of $\mathrm{HNO}_{3}(65 \%)$ :
$\mathrm{HClO}_{4}(68 \%),(5: 2) \mathrm{v} / \mathrm{v}$ at $180^{\circ} \mathrm{C}$ per 60 minutes using a heating digester DK 6 (VELP ${ }^{\oplus}$ Scientifica, Usmate, Italy) to obtain the metal concentration, which was, for each sample, multiplied by the total volume of collected rainwater in order to obtain the total quantity of each metal. The primary aim was not to compare the effect of species but to compare the effect of presence or absence of shrubs on the metal content in runoff water.

Plant height and crown diameter were measured on six shrubs (three per belt) per species in May, July, and October 2011. On the same sampling dates, leaf area index (LAI) was measured by a ceptometer (AccuPAR LP-80, Decagon Devices, Inc., Pullman, Washington, U.S.) at $1 \mathrm{~m}$ above the ground. In October, the total leaf area of four shrubs per species was measured by destructive harvest. The depositions of trace metals on the whole plant were then calculated by multiplying the depositions per unit leaf area and the whole plant leaf area.

Morphology of the leaf surface and presence of particulate matter on the abaxial and adaxial surfaces were observed on ten leaves per species from one sampling event in July using an ESEM (electron scanning environmental microscope) Quanta 200, (Fei Corporation, Eindhoven, The Netherlands), operating in low-vacuum mode (chamber pressure was kept at 1 Torr) and $25 \mathrm{kV}$. Leaves to be observed by ESEM were harvested using separate disposable gloves for each species; leaves were harvested from the petioles, avoiding contact with the leaf blade. After harvesting, leaves were carefully placed in disposable paper bags and immediately processed.

Meteorological parameters (rainfall, wind speed, wind direction, relative humidity, and airtemperature) were measured continuously from June to October 2011 at $1.5 \mathrm{~m}$ height, using an iMetos $^{\circledast}$ SD meteorological station (Pessl Instruments, Weiz, Austria) positioned between the vegetation belts (15 $\mathrm{m}$ distant from each belt).

\section{Statistical Analysis}

Growth parameters and water relationships were analyzed using one-way (Exp. 1) or twoway ANOVA (Exp. 2). Leaf gas exchange data were analyzed using repeated measures ANOVA. Mean separation was carried out using Duncan's MRT (SPSS statistics 19, IBM Company, New York, U.S). Differences in trace metal deposi- 
tions (Exp. 3) were tested with repeated measures ANOVA and separation of the means was carried out using Duncan's MRT (CoStat 6.303, CoHort Software, Monterey, California, U.S.). The relationships between metal depositions on leaves and climate parameters were tested using Partial Least Square Regression (PLSR) for each metal separately. PLSR is useful when a high level of multi-collinearity among the explanatory variables is assumed (Rosipal and Trejo 2001). Correlations between the deposited metals were tested using Pearson product-moment correlation coefficients ( $r$ ) and only the $r$ values above 0.5 were considered. Multivariate methods were used to identify the possible sources of different metals. Cluster Analysis (CA) was performed using Ward's method and Euclidean distance as metric (Oliva and Espinosa 2007). Factor Analysis (FA) was accomplished with Varimax rotation (Lorenzini et al. 2006). The outliers were identified and removed from the data set.

\section{RESULTS}

\section{Experiment 1: Carbon Uptake Under Optimal Water Availability}

Elaeagnus $\times$ ebbingei, A. unedo, and L. nobilis had the highest mean daily $\mathrm{CO}_{2}$ assimilation per unit leaf area compared to the other species when shrubs were grown under optimal water availability (Figure 2A). Conversely, V. lucidum, L. japonicum, and V. tinus showed the lowest values. All species showed the highest values of $\mathrm{CO}_{2}$ assimilation during the morning hours and then underwent a significant midday depression. Elaeagnus $\times$ ebbingei and L. japonicum, in contrast with the other species, showed a significant recovery of $\mathrm{CO}_{2}$ assimilation, reaching values similar to those in the morning, after 3:00 pm.

$\mathrm{CO}_{2}$ assimilation of the whole plant (a parameter that considers both the assimilation per unit leaf area and the total leaf area of the plant) was higher in E. $\times$ ebbingei and L. nobilis than in $V$. lucidum, $V$. tinus, and $P . \times$ fraseri; $A$. unedo and $L$. japonicum showed the lowest values (Figure 2B).

Species had different WUE ( $V$. lucidum $=3.87$ $\pm 2.35 ;$ A. unedo $=3.93 \pm 1.86 ; P . \times$ fraseri $=4.71$ \pm 2.51 ; L. nobilis $=4.86 \pm 2.14 ;$ E. $\times$ ebbingei $=$ $4.76 \pm 2.34$; L. japonicum $=4.09 \pm 2.06 ; V$. tinus $=4.36 \pm 2.60$ expressed as $\mu \mathrm{mol} \mathrm{CO} \mathrm{Cmol}^{-1} \mathrm{H}_{2} \mathrm{O}$ ).
Laurus nobilis and E. $\times$ ebbingei gave the highest woody biomass production (data not shown) and the highest relative growth rate calculated over the experimental period (Figure 2C). A positive strong correlation $\left(P<0.01 ; \mathrm{R}^{2}=0.95\right)$ was found between whole-plant $\mathrm{CO}_{2}$ assimilation and relative growth rate (Figure 2D).

Allocation of photosynthates among plant organs differed across species. V. lucidum allocated more carbon to leaves compared to all other species. On the contrary, V. tinus, E. $\times$ ebbingei, and L. japonicum displayed lower percentages of $\mathrm{C}$ allocation to leaves compared to the other species considered, even if differences were significant only when compared to V. lucidum (Figure 3). At the end of the experiment, E. $\times$ ebbingei, L. nobilis, V. lucidum, and $V$. tinus had higher total leaf area $(0.29 \pm 0.05$; $0.32 \pm 0.04 ; 0.27 \pm 0.04 ; 0.30 \pm 0.05 \mathrm{~m}^{2}$, respectively) than A. unedo, P. $\times$ fraseri, and L. japonicum (0.18 $\pm 0.03 ; 0.19 \pm 0.05 ; 0.16 \pm 0.05 \mathrm{~m}^{2}$, respectively).

\section{Experiment 2: Carbon Uptake and Storage Under Drought Stress}

On average, substrate moisture of WS shrubs declined to $15 \%$ of its holding capacity by the end of "drought phase 1" (T-3), where it was maintained around $30 \%$ by irrigation until T- 4 and finally declined to $12 \%$ at the end of "drought phase 2" (T-5) (Figure 4A). $\mathrm{CO}_{2}$ assimilation of WW shrubs largely confirmed the values observed in Experiment 1 (data not shown) and did not statistically differ from data collected from WS shrubs at T-0. As drought progressed (T-1,T-2, $\mathrm{T}-3), \mathrm{CO}_{2}$ assimilation declined in all species, but the magnitude of the decline was species-specific, with species such as $E . \times$ ebbingei and $V$. lucidum experiencing greater drought-induced reductions in $\mathrm{CO}_{2}$ assimilation than $V$. tinus and $A$. unedo. During partial relief (T-4), $\mathrm{CO}_{2}$ assimilation of some species (i.e., P. $\times$ fraseri, V. tinus, L. japonicum) exhibited some recovery, while in other species (i.e., E. $\times$ ebbingei, A. unedo, V. lucidum) $\mathrm{CO}_{2}$ assimilation showed little or no recovery. At the end of drought phase 2 (T-5), A. unedo, P. $\times$ fraseri, V. tinus, and L. japonicum had higher $\mathrm{CO}_{2}$ assimilation than E. $\times$ ebbingei and V. lucidum. However, as drought progressed, $\mathrm{CO}_{2}$ assimilation of E. $\times$ ebbingei was strongly reduced (Figure 4B). A similar trend was found in V. lucidum, which 


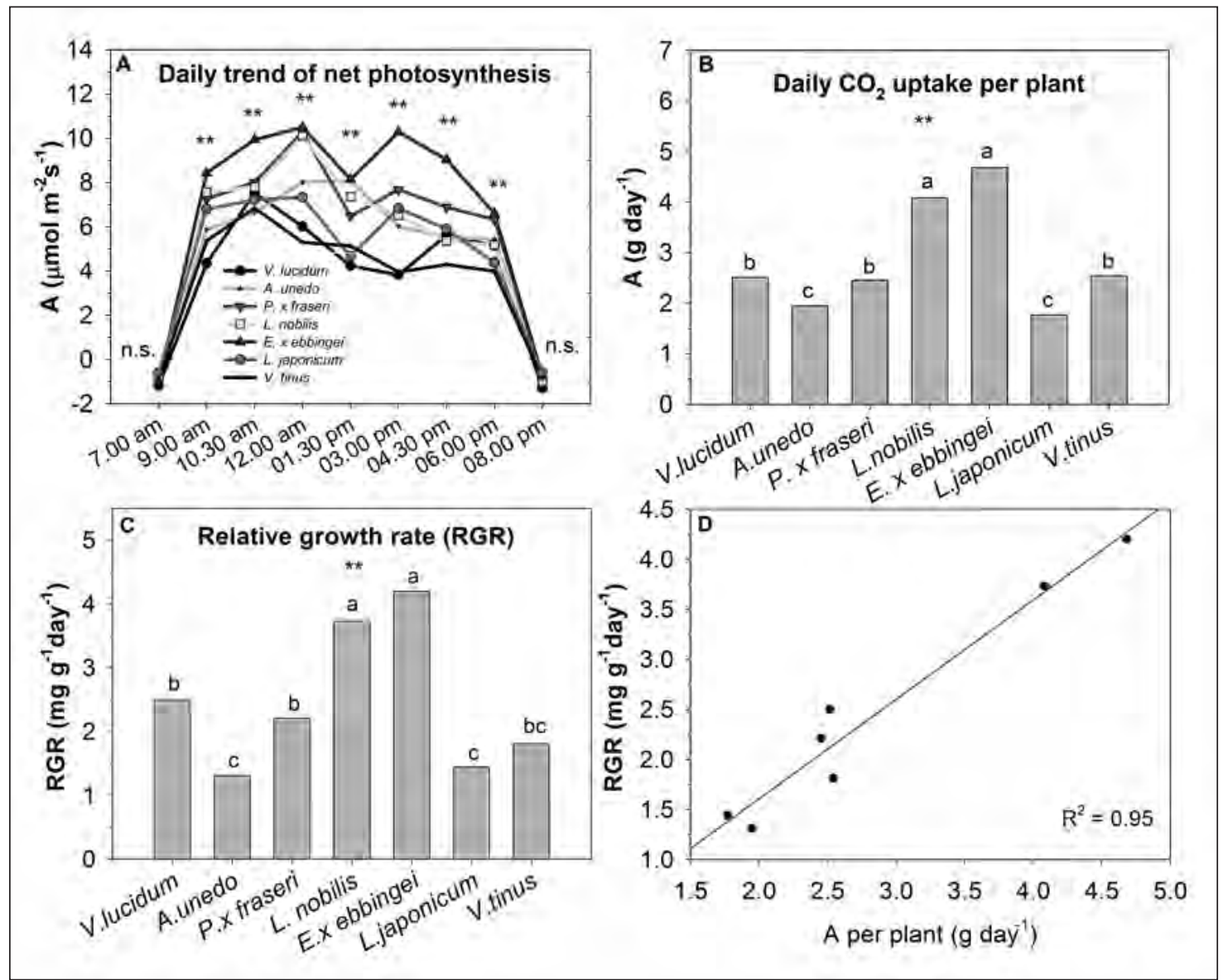

Figure 2. A) Daily trend of net photosynthesis expressed as $\mu \mathrm{mol}\left(\mathrm{CO}_{2}\right) \mathrm{m}^{-2}$ (leaf area) $\mathrm{s}^{-1}$; B) daily $\mathrm{CO}_{2}$ uptake of the whole plant expressed as $\mathrm{g}\left(\mathrm{CO}_{2}\right.$ assimilated) day ${ }^{-1}$; C) relative growth rate (RGR); and $\left.\mathrm{D}\right)$ relation between RGR and whole-plant daily $\mathrm{CO}_{2}$ assimilation of seven different shrubs in 2011, under optimal water availability. Data of $\mathrm{CO}_{2}$ uptake are the average of 12 daily measurements of net photosynthesis. Double asterisk (**) indicates significant differences among species at $\boldsymbol{P}<0.01$, different letters indicate different homogeneous groups using Duncan's MRT.

had a very low $\mathrm{CO}_{2}$ assimilation during drought. Viburnum tinus and A. unedo had the smallest reduction in $\mathrm{CO}_{2}$ assimilation under drought stress.

Drought differentially reduced the maximum quantum yield of PSII photochemistry (Fv/Fm) during drought phase 1 (Figure 5). Ligustrum japonicum, E. $\times$ ebbingei, and $V$. lucidum showed the highest depletion in Fv/Fm, whereas $P . \times$ fraseri displayed the lowest deviation. In particular, $\mathrm{Fv} / \mathrm{Fm}$ decreased below 0.70 in $L$. japonicum and $V$. lucidum, indicating a condition of stress.

\section{Experiment 3: Leaf Deposition of Trace Metals}

Species differed for $\mathrm{Pb}$ deposition on unit leaf surfaces while differences were not statistically significant for other metals (Table 3). Ligustrum

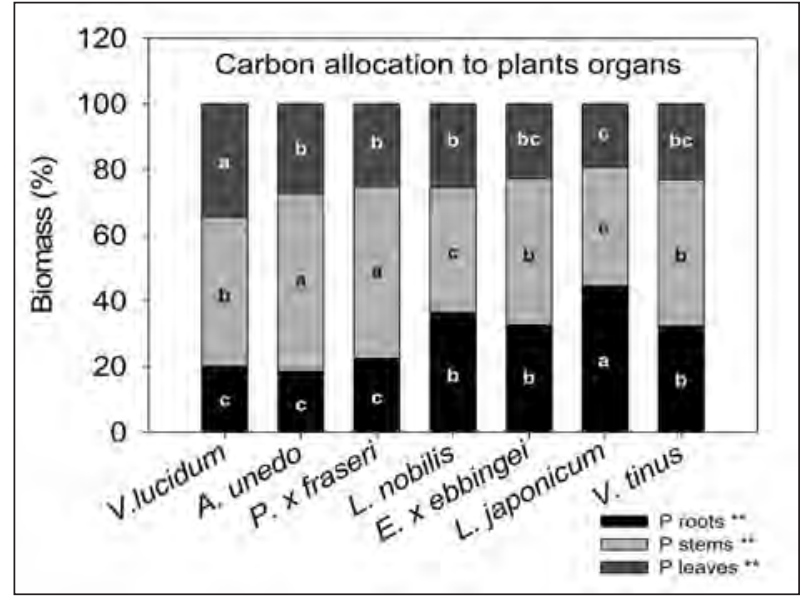

Figure 3. Carbon allocation to different plant organs in seven shrub species in 2011 under optimal water availability. Different letters within an organ (i.e., leaves, stem, and roots) indicate significant differences among species at $P<0.01$ using Duncan's MRT. 


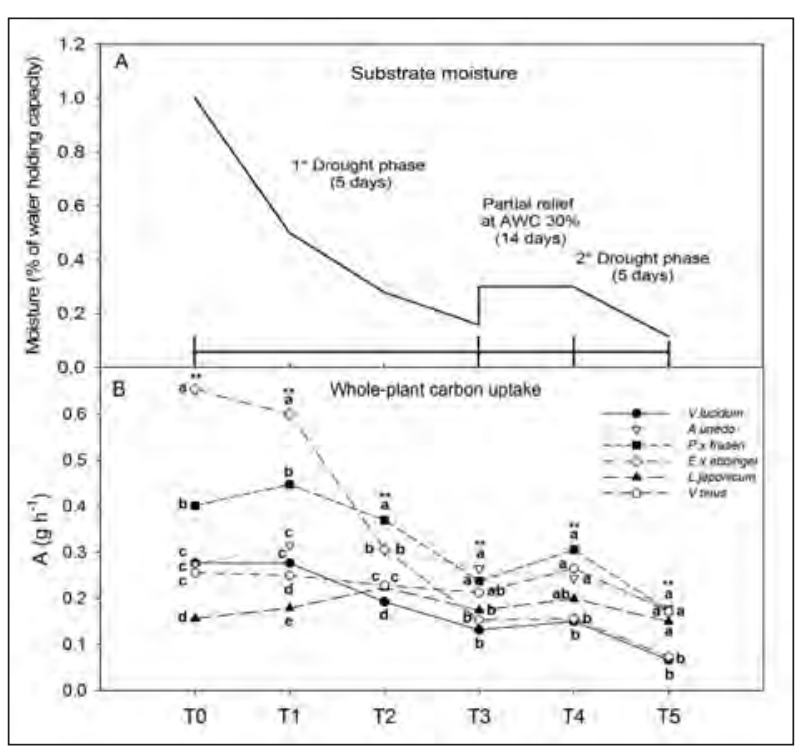

Figure 4. A) Irrigation scheduling and substrate moisture (expressed as percentage of the water holding capacity of the container), for plants under drought stress (WS); and B) Whole plant carbon uptake in six shrubs grown under water stress in 2012 expressed as $\mathbf{g}\left(\mathrm{CO}_{2}\right.$ assimilated) per $\mathrm{h}^{-1}$. Data of substrate moisture are the average 12 plants per species for six species. $T$ indicates when physiological measurements were carried out. Different letters within the same sampling date indicate significant differences among species at $\boldsymbol{P}>0.01$ using Duncan's MRT.

japonicum, E. $\times$ ebbingei, and V. lucidum had higher $\mathrm{Pb}$ depositions per unit leaf area than $L$. nobilis. The quantity of $\mathrm{Cu}, \mathrm{Ni}, \mathrm{Pb}$, and $\mathrm{Zn}$ deposited on the whole canopy was significantly higher in E. $\times$ ebbingei than in the other species.

Generally, deposition of metals increased from early to mid-summer (June-August) and thereafter decreased to October levels comparable to those in June (Figure 6). All metals, with the exception of $\mathrm{Pb}$, presented a significantly different seasonal trend $(P<0.001)$. Partial least square regression analysis (Table 4 ), with four out of five significant results, suggests that the leaf metal depositions are negatively related to precipitation and $\mathrm{RH} \%$ and positively related to air temperature and wind velocity.

The photos taken by ESEM (Figure 7) reveal the clear presence of particulate matter on the upper and lower leaf surfaces of all species with a greater quantity of trapped PM in the hairy leaves of $E . \times$ ebbingei when compared to the other (smooth-leaved) species.

\section{Metal Washout from the Canopy}

The rainwater collected at the base of all species, except $V$. lucidum, showed greater quantities of $\mathrm{Zn}$, $\mathrm{Cu}$, and $\mathrm{Pb}$ compared to control samples (Figure 8).

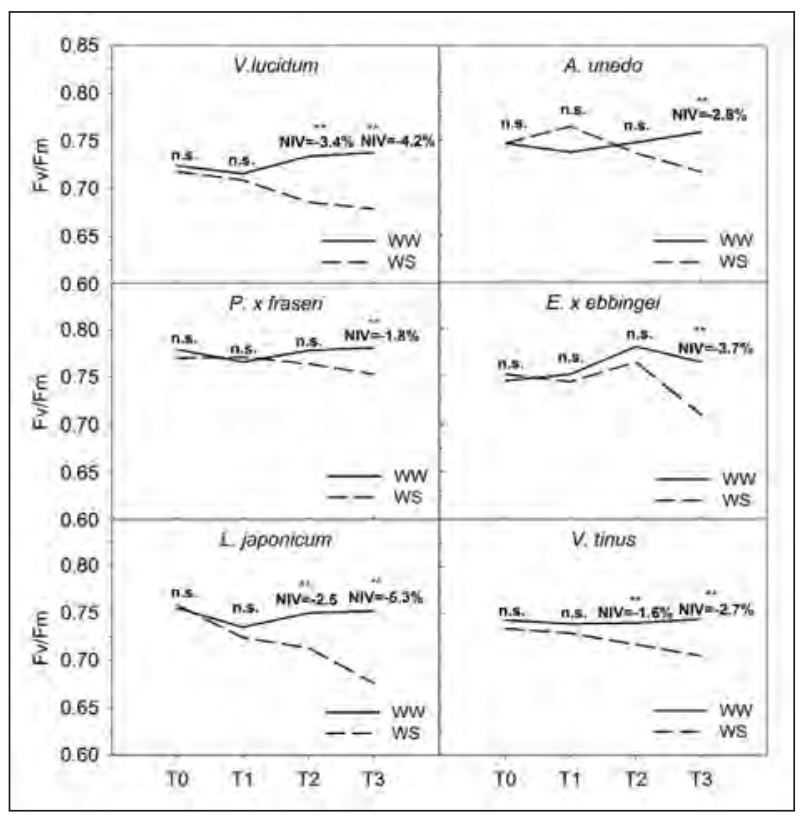

Figure 5. Maximum quantum yield of PSII photochemistry during the "drought phase 1" in six shrubs grown under either well watered (WW) or water stress (WS) conditions. Double asterisk $\left({ }^{*}\right)$ indicates significant differences between WW and WS plants of a species for $P>0.01$ using Duncan's MRT. The normalized index of variation (NIV) was calculated as: $\left[(\mathrm{Fv} / \mathrm{Fm})_{\mathrm{ws}}-(\mathrm{Fv} / \mathrm{Fm})_{\mathrm{ww}}\right] /\left[(\mathrm{Fv} / \mathrm{Fm})_{\mathrm{ws}}+\right.$ $(\text { Fv/Fm })_{\text {ww }}$ (Tattini et al. 2006).

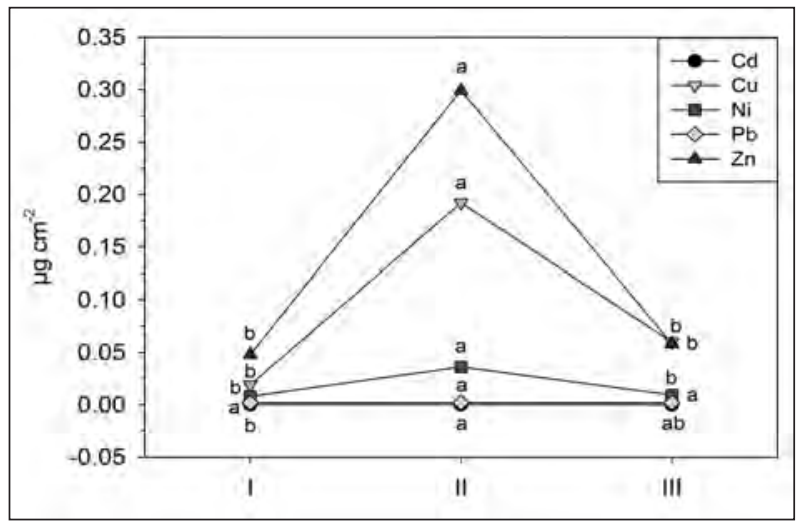

Figure 6. Metal depositions on leaf surface, expressed as $\mu \mathrm{g}$ (metal) $\mathrm{cm}^{-2}$ (leaf area), in the different periods during growth season of 2011: 21 June 2011 (I); 03 August 2011 (II); 04 October 2011 (III); 30 August values are means of all species $\left(\mu \mathrm{g} \mathrm{cm}^{-2}\right)$. Different letters within the same sampling date indicate significant differences among species at $\boldsymbol{P}>$ 0.01 using Duncan's MRT. 


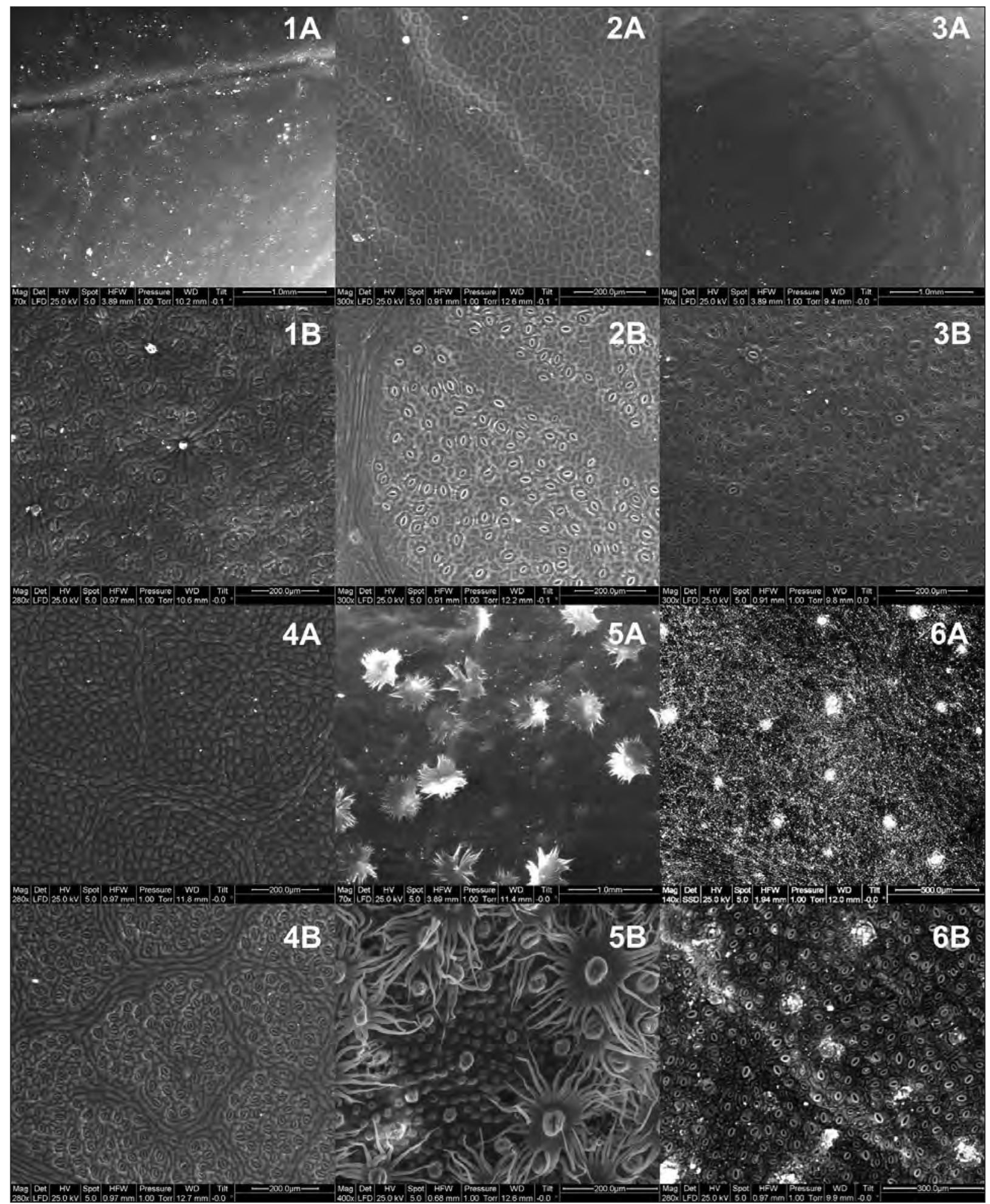

Figure 7. Environmental scanning electron microscope (ESEM) micrographies: A) adaxial and B) abaxial leaf surface of (1) Viburnum lucidum, (2) Arbutus unedo, (3) Photinia $\times$ fraseri, (4) Laurus nobilis, (5) Elaeagnus $\times$ ebbingei, and (6) Ligustrum japonicum. Images were taken at different magnifications as reported on the images. 


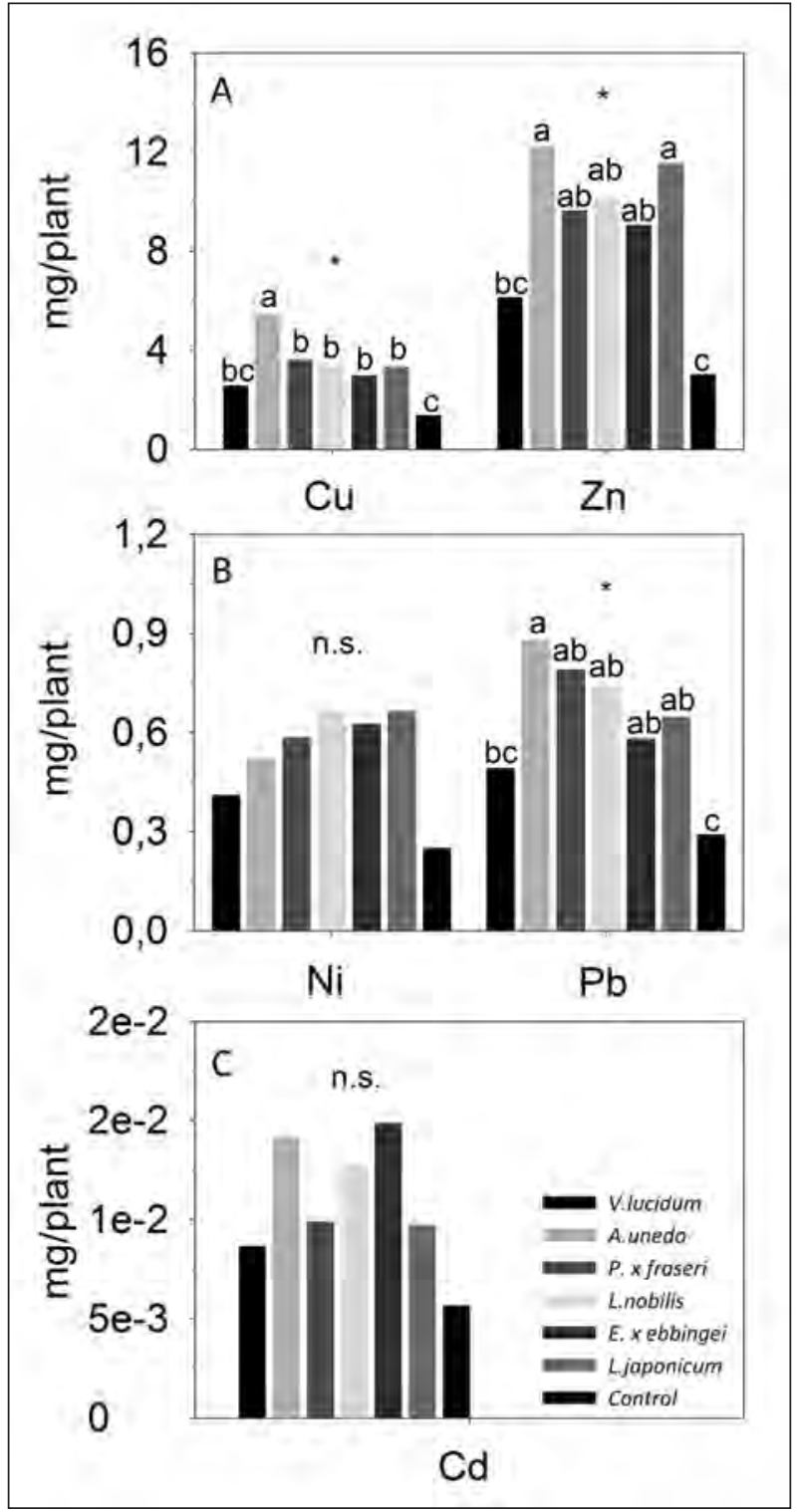

Figure 8. A) Accumulation of $\mathrm{Cu}$ and $\mathrm{Zn}$; $\mathrm{B}$ ) $\mathrm{Ni}$ and $\mathrm{Pb}$; C) and Cd expressed as $\mathrm{mg}$ (metal) / plant, from June to October 2011 in the water collected at the base of Viburnum lucidum, Arbutus unedo, Photinia $\times$ fraseri, Laurus nobilis, Elaeagnus $\times$ ebbingei, Ligustrum japonicum, and control. Values are means (mg/plant). Different letters within the same sampling date indicate significant differences among species at $P<0.05\left(^{*}\right)$ using Duncan's MRT.

\section{Metal Source Identification}

Cluster analysis, which is generally used to group variables (metals) based on their similarity/ dissimilarity, grouped the metals in two principal clusters. The first cluster included $\mathrm{Cu}$ and $\mathrm{Ni}$, while $\mathrm{Cd}, \mathrm{Zn}$, and $\mathrm{Pb}$ were located in the second (Table 5). Factor Analysis (Table 5), which has the aim of describing variability among variables by a lower number of artificial variables (factors), indicated that approximately $85 \%$ of the variance may be explained by the first two factors. Factor 1, which accounted for $58 \%$ of total variance, showed positive loadings with $\mathrm{Cu}, \mathrm{Ni}$, and $\mathrm{Zn}$. In factor 2 (27\% of total explained variance), $\mathrm{Cd}$ and $\mathrm{Pb}$ were dominant metals. Correlation analysis between leaf metal depositions showed that $\mathrm{Cd}$ is correlated with $\mathrm{Pb}(\mathrm{r}=0.51)$, $\mathrm{Cu}$ with $\mathrm{Ni}$ and $\mathrm{Zn}$ (respectively $r=0.92$ and 0.83$)$, and Ni with $\mathrm{Zn}(r=0.77)$.

\section{DISCUSSION}

\section{Experiments 1 and 2: $\mathrm{CO}_{2}$ Uptake Under Contrasting Water Availability}

Experiments 1 and 2 were aimed at investigating $\mathrm{CO}_{2}$ assimilation and storage of seven widely used evergreen shrub species under either optimal moisture availability (Exp. 1) or water stress (Exp. 2). The results of these experiments corroborate the idea that the "carbon benefit" of shrubs is largely speciesspecific and dependent on a species-planting site interaction, as previously observed with tree species (Nowak and Crane 2002; McPherson and Simpson 2003). In particular, the ecological behavior of the species and the mechanisms evolved to cope with environmental stress are key determinants of carbon assimilation and carbon storage (Penuelas et al. 2001; West et al. 2012). The data highlight different growth strategies by the seven species investigated, which may be critical for proper use of these shrubs in the landscape. Some shrub species (i.e., $E$ $\times$ ebbingei, V. lucidum, and L. japonicum) displayed a profligate/opportunistic water use (in the sense intended by Moreno-Gutiérrez et al. 2012), characterized by high water use and $\mathrm{CO}_{2}$ assimilation per unit leaf area when water is not limiting, and drastic reduction of stomatal conductance, transpiration, and $\mathrm{CO}_{2}$ assimilation after the onset of stress. Other species (i.e., A. unedo and V. tinus), instead, have evolved a conservative water-use strategy, consisting in relatively low leaf gas exchange during the favorable periods, which was only slightly depressed during stress (Moreno-Gutiérrez et al. 2012).

These findings have important applications for sustainable and benefit-based planning of urban green areas. In moist and favorable sites, or where irrigation water is readily available, $\mathrm{CO}_{2}$ assimilation and carbon storage are highly correlated 
Table 3. Foliar deposition, per unit leaf area and per the whole canopy, of six shrub species of five trace metals (Cd, Cu, $\mathrm{Ni}, \mathrm{Pb}$, and $\mathrm{Zn}$ ). Data are the mean of three samplings performed in June, August, and October. Data are means $\pm \mathrm{SD}$. ANOVA tests (A) of differences between species are also included. Values as 0.000 are less than 0.001 .

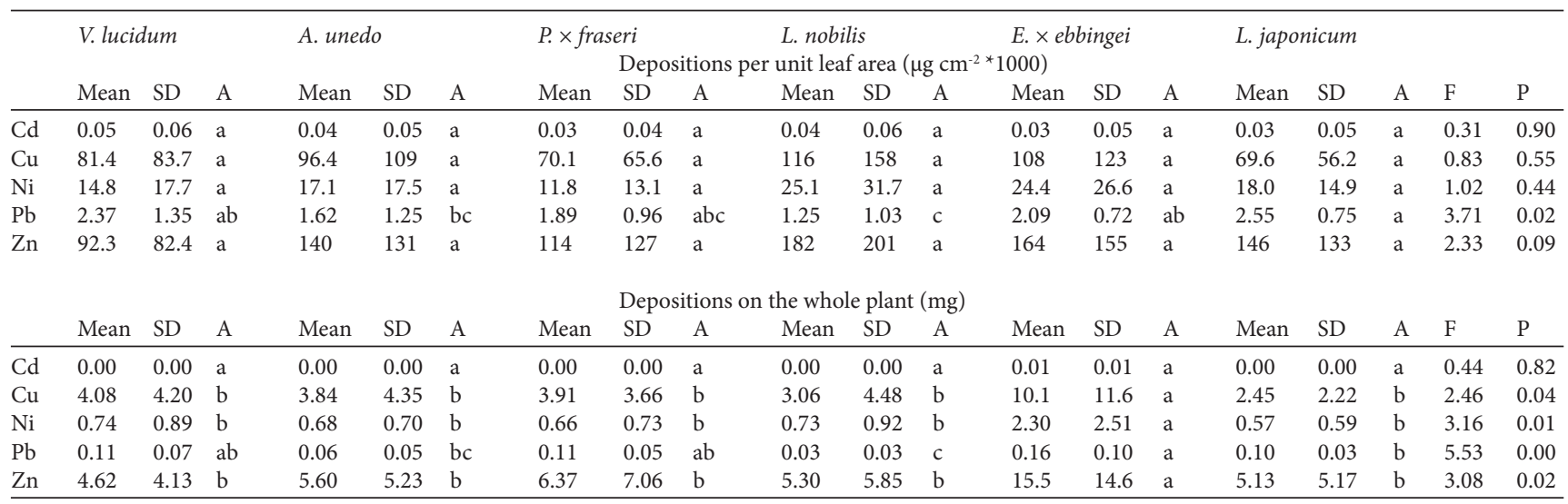

Table 4. Partial least square regression analysis (PLSR) coefficients showing how deposition of different metals depends on wind velocity (Wind), air temperature (Air $\mathrm{T}^{\circ}$ ), relative humidity $(\mathrm{RH} \%)$, and precipitation (Prec.). Values as 0.000 are not equal to 0 but less than 0.001 .

\begin{tabular}{llllllll}
\hline & $\mathrm{F}$ & $P$ & $\mathrm{r}^{2}$ & Const. & Wind & Air T \\
\hline $\mathrm{Cd}$ & 10.74 & 0.002 & 15 & -0.000 & 0.000 & 0.000 & -0.000 \\
$\mathrm{Cu}$ & 34.41 & 0.000 & 53 & -0.732 & 0.486 & -0.000 \\
$\mathrm{Ni}$ & 19.98 & 0.000 & 40 & -0.121 & 0.086 & -0.009 \\
$\mathrm{~Pb}$ & 3.24 & 0.077 & 5 & -0.001 & 0.002 & -0.001 & 0.000 \\
$\mathrm{Zn}$ & 128.18 & 0.000 & 67 & -1.159 & 0.801 & -0.001 & -0.000 \\
\hline
\end{tabular}

(Herms and Mattson 1992). Under these conditions, the planting of profligate/opportunistic species with a high assimilation rate is highly advisable because they allow maximization of both $\mathrm{CO}_{2}$ assimilation and growth. Among the species studied here, E. $\times$ ebbingei and L. nobilis outperformed the others under non-limiting moisture in terms of carbon uptake and growth. In detail, E. $\times$ ebbingei showed the highest $\mathrm{CO}_{2}$ assimilation rates per unit leaf area throughout the day, and particularly during the afternoon, when photosynthesis of most of the other species was greatly constrained by midday depression. Furthermore, this species, when grown with adequate moisture, can sustain these rates over a large leaf area, resulting in higher daily carbon uptake per individual plant compared to most of the other species investigated. On the contrary, other species, such as $P . \times$ fraseri and $L$. japonicum, had high $\mathrm{CO}_{2}$ assimilation rates but low total leaf area per plant, resulting in lower daily $\mathrm{CO}_{2}$ assimilation and growth rates compared to E. $\times$ ebbingei and L. nobilis.

It must also be considered that, for a given increase in plant biomass, species that invest more in leaves than in woody biomass store carbon for a shorter period, particularly in the urban environment where fallen leaves are artificially removed
Table 5. Clusters derived from cluster analysis and factor loadings of two factors identified from factor analysis for metals on leaves during the entire sampling period. Varimax rotation was applied to factor analysis.

\begin{tabular}{llll}
\hline & Cluster & Factor 1 & Factor 2 \\
\hline $\mathrm{Cd}$ & 2 & 0.25 & $\mathbf{0 . 8 3}$ \\
$\mathrm{Cu}$ & 1 & $\mathbf{0 . 9 7}$ & 0.09 \\
$\mathrm{Ni}$ & 1 & $\mathbf{0 . 9 6}$ & 0.01 \\
$\mathrm{~Pb}$ & 2 & -0.02 & $\mathbf{0 . 8 9}$ \\
$\mathrm{Zn}$ & 2 & $\mathbf{0 . 8 8}$ & 0.28 \\
\hline
\end{tabular}

(Nowak et al. 2002). Therefore, species such as $V$. lucidum, with a high carbon allocation to leaves, may not be advisable for maximizing carbon storage.

Drought stress reduces plant carbon gain by acting on both stomatal and mesophyll conductance, and affecting the activity of Rubisco and the rate of ribulose regeneration (Chaves et al. 2002; Medrano et al. 2002). Furthermore, drought can alter photosynthate partitioning to primary (growth) and secondary (defense) metabolism, thereby decreasing the amount of assimilated carbon stored as woody biomass. For example, in a recent experiment, when shrubs of the isoprene emitter species Platanus $\times$ acerifolia were moved from a moist to a dry environment, the amount of photosynthate allocated to isoprene (a defense compound) was unchanged, 
despite a five-fold reduction of photosynthesis (Tattini et al. 2015). Clearly, if photosynthesis is impaired, secondary metabolism is fed by reserves that then become unavailable for growth (Loreto and Schnitzler 2010); the more the stress is perceived as severe by the plant, the more primary metabolism is likely to be affected. Finally, when a plant is killed by drought, the carbon stored in its woody organs will return to the atmosphere, unless the woody material is properly managed (i.e., soil amendment) (Nowak and Crane 2002). Therefore, when planting harsh sites with the aim of improving $\mathrm{CO}_{2}$ sequestration, it is necessary to plant species that are "horticulturally tolerant"; that is, drought-tolerant species capable of sustaining carbon gain and growth under stressful conditions (see Fini et al. 2013), or their benefits will be greatly reduced or neglected.

Species with conservative water use, such as the Mediterranean shrubs A. unedo and $V$. tinus, had lower stomatal conductance and carbon assimilation than profligate/opportunistic species under non-limiting water availability, but maintain relatively high leaf gas exchange during drought. The capacity of $A$. unedo and $V$. tinus to preserve the functionality of the photosynthetic apparatus during drought is confirmed by the lower decline in the maximum quantum yield of photosystem II (Fv/ Fm) compared to profligate/opportunistic species, such as E. $\times$ ebbingei, L. japonicum, and V. lucidum. When $\mathrm{CO}_{2}$ assimilation is largely constrained by water shortage, as occurs in profligate/opportunistic species, usage of irradiance in the photosynthetic process is also reduced, and leaves may experience severe excess light stress, leading to photoinhibition and photo-oxidative damage (Chaves et al. 2008; Fini et al. 2012). The large drop in Fv/ Fm observed in E. $\times$ ebbingei, L. japonicum, and $V$. lucidum indicates that photo-inhibition probably occurred in leaves of these species during drought (Percival 2005; Kalaji et al. 2012; Fini et al. 2013).

Although severe drought induced a decline of photosynthesis, $P . \times$ fraseri displayed the lowest decline in Fv/Fm. The high concentration of anthocyanins in this red-leafed species may explain its notable capacity to counter excess light stress and avoid severe photoinhibition during water stress (Tattini et al. 2015).

In summary, the results of Experiments 1 and 2 indicate that, if maximizing $\mathrm{CO}_{2}$ assimilation and carbon storage is a project goal, species with a profligate/opportunistic water use and fast growth rate, such as E. $\times$ ebbingei and L. nobilis, should be planted in moist/irrigated planting sites, while species with a conservative water use or effective photoprotective mechanisms (A. unedo, V. tinus, $P . \times$ fraseri) are recommended for drought-prone environments.

A potential limitation of this study is that the life spans of the different species were not considered. Thus, while the results may be valuable for understanding $\mathrm{CO}_{2}$ assimilation and carbon storage of different shrub species per unit time, they may not reflect the total carbon stored over the whole life of the plant. However, with the exception of A. unedo, which can live for up to 400 years, the life span of the other shrub species is similar, ranging from 20 to 50 years (Clemson Cooperative Extension 2015; AUB Landscape Plant Database 2016; European Trees 2016). In addition, all the three species (A. unedo, V. tinus, $P . \times$ fraseri) have similar size at maturity, ranging from 3 to $7 \mathrm{~m}$ (Brikell 2008).

These life spans fit the normal turnover of green areas in urban environments well, where plants often decline because of multiple stresses and are not likely to complete their life cycles (Kozlowski 1999).

\section{Experiment 3: Leaf Deposition of Trace Metals}

Leaf deposition per unit leaf area of $\mathrm{Pb}$ differed among species, while for the other metals adsorption was not affected by species. In addition, the species that showed the highest quantities of $\mathrm{Pb}$ (L. japonicum, V. lucidum, and E. $\times$ ebbingei) had no specific common characteristics (e.g., presence of leaf trichomes, high growth parameters) differentiating them from the other species (Table 6 ; Figure 7). Elaeagnus $\times$ ebbingei is the only species with a visible presence of trichomes that can be related to a higher capacity of pollutant retention (Beckett et al. 2000). Ligustrum japonicum and $V$. lucidum, unlike the other species, showed the presence of secretory glands, especially on the lower leaf surface (Figure 8). Secretory activity is evident by the light color of the glands, indicating of the presence of salts (Sakai 1974), which may be related to the higher values of $\mathrm{Pb}$ in the aforementioned species. Lavid et al. (2001) found that $\mathrm{Pb}$ may be excreted by leaves through epidermal glands, and this is consistent with the limited 
seasonal variability observed across samplings in this study. In fact, the secretory activity may be considered independent from meteorological conditions, which on the other hand, affect the leaf depositions of metals from the PM in the air.

The results of whole-plant leaf deposition suggest that total leaf area had a greater effect on the interception capacity of shrubs than the morphoanatomical traits of individual leaves (Table 6). Rapid-growing species with large total leaf area, and high LAI, crown diameters, and height, have been reported to adsorb more pollutants than slowergrowing species (Bunzl et al. 1989; Beckett et al. 2000; Fowler et al. 2003; Freer-Smith et al. 2005).

The large variation in metal deposition during samplings confirmed that leaves are a temporary retention site for pollutants (Nowak et al. 2006). The results of partial least square regression, especially for $\mathrm{Cu}$ and $\mathrm{Zn}\left(\mathrm{r}^{2}\right.$ above 50 ), make it possible to predict the deposition of metals with moderate accuracy by using climatic parameters (Table 4). The negative relationship between metal deposition and total rainfall indicates that metals on leaves decreased as rain increased, confirming the washout effect that rain quickly plays on pollutants adsorbed on leaf surfaces (Nowak et al. 2006). The inverse relationship between metal deposition and $\mathrm{RH} \%$ may be considered more a consequence of the strong relationship between rain and $\mathrm{RH} \%$ than a direct effect of $\mathrm{RH} \%$ on metal deposition. Despite this, it is reported that $\mathrm{RH} \%$ causes an increase in PM diameter and that when PM diameters are greater than $0.1 \mu \mathrm{m}$, an increase in diameter leads to an increase of deposition velocities (Fowler et al. 2003; Litschke and Kuttler 2008). The positive relationship between metals and wind speed could be due to the fact that increasing wind speed leads to increasing deposition velocities of PM (Beckett et al. 2000).
Temperature was also found to have a positive relationship with the deposition of pollutants, as previously reported (Cavanagh et al. 2009).

\section{Washout by Rain of Metals from the Canopy}

The protocol used for rainwater collection does not allow exclusion of possible contamination of samples because of bird droppings, insects, or other undesired animals. Therefore, researches focused mainly on differences between the presence and absence of plants, rather than on differences among species. The greater quantities of metals in containers under shrubs is further demonstration of the role of shrubs in intercepting air pollution (Nowak et al. 2000; Bealey et al. 2007). In addition, the effect of washout caused by rain, and the consequent deposition on the ground of metals, helps reduce the resuspension of pollutants in the air.

\section{Metal Source Identification}

The results of correlation, FA, and CA were compared in order to identify the possible source(s) of different metals. $\mathrm{Cu}, \mathrm{Ni}$, and $\mathrm{Zn}$ have high loadings in factor 1 of FA and are all strongly correlated (Table 5). Meanwhile CA clustered $\mathrm{Cu}$ and $\mathrm{Ni}$ in a different group compared to $\mathrm{Zn}$; $\mathrm{Zn}$ was then excluded from the analysis. The relationship between $\mathrm{Cu}$ and $\mathrm{Ni}$ is then supported by three different statistical methods. $\mathrm{Cd}$ and $\mathrm{Pb}$ are dominant in factor 2 of FA and are significantly correlated. Moreover, in CA, they are clustered together in Group 2. Thus, the relationship between Cd and $\mathrm{Pb}$ is confirmed by three different methods. Considering these results, two different groups were created: Group $1(\mathrm{Cu}$ and $\mathrm{Ni})$ and Group $2(\mathrm{~Pb}$ and $\mathrm{Cd})$. All four of these metals have previously been attributed to traffic emissions (Pant and Harrison, 2013; Valotto et al. 2015). This division

Table 6. Leaf area of the whole plant (LA), leaf area index (LAI), average lamina size (LS), number of leaves per plant $\left(N^{\circ} \mathrm{L}\right)$, crown diameter (CD), and height of plants (HP), of six shrub species planted in a field near a heavily polluted road (Exp. 3). Values are means \pm SD. ANOVA tests (A) of differences between species are also included.

\begin{tabular}{|c|c|c|c|c|c|c|c|c|c|c|c|c|c|c|c|c|c|c|c|c|}
\hline & \multicolumn{3}{|c|}{ V. lucidum } & \multicolumn{3}{|c|}{ A. unedo } & \multicolumn{3}{|c|}{$P . \times$ fraser $i$} & \multicolumn{3}{|c|}{ L. nobilis } & \multicolumn{3}{|c|}{ E. $\times$ ebbingei } & \multicolumn{3}{|c|}{ L. japonicum } & \multirow[b]{2}{*}{$\mathrm{F}$} & \multirow[b]{2}{*}{$P$} \\
\hline & Mean & SD & A & Mean & SD & A & Mean & SD & A & Mean & SD & A & Mean & SD & A & Mean & SD & A & & \\
\hline $\mathrm{LA}\left(\mathrm{m}^{2}\right)$ & 5.01 & 0.67 & $\mathrm{bc}$ & 3.99 & 0.39 & $a b$ & 5.58 & 1.58 & c & 2.9 & 0.24 & $\mathrm{a}$ & 9.43 & 0.68 & d & 3.87 & 0.56 & $\mathrm{ab}$ & 24.3 & 0.00 \\
\hline LAI & 5.43 & 1.12 & $c$ & 3.9 & 0.97 & $\mathrm{a}$ & 5.32 & 0.88 & c & 4.47 & 1.26 & $\mathrm{~b}$ & 6.9 & 1.14 & $\mathrm{~d}$ & 4.15 & 1.08 & $\mathrm{ab}$ & 17.6 & 0.00 \\
\hline $\mathrm{LS}\left(\mathrm{cm}^{2}\right)$ & 31.9 & 5.66 & $c$ & 10.5 & 2.68 & $\mathrm{a}$ & 19.5 & 1.45 & $\mathrm{~b}$ & 20.8 & 4.17 & $\mathrm{~b}$ & 12.6 & 1.49 & $\mathrm{a}$ & 17.3 & 2.04 & $\mathrm{~b}$ & 31.6 & 0.00 \\
\hline $\mathrm{N}^{\circ} \mathrm{L}$ & 1608 & 265 & $\mathrm{ab}$ & 3967 & 898 & $\mathrm{~d}$ & 2876 & 226 & c & 1443 & 271 & $\mathrm{a}$ & 7611 & 1045 & e & 2268 & 284 & bc & 88.1 & 0.00 \\
\hline $\mathrm{CD}$ & 102 & 7.06 & d & 93.1 & 6.45 & c & 102 & 13.2 & $\mathrm{~d}$ & 71.6 & 12.2 & $\mathrm{a}$ & 108 & 11.7 & $\mathrm{~d}$ & 81.5 & 14.4 & $\mathrm{~b}$ & 25.2 & 0.00 \\
\hline HP & 146 & 16.8 & $\mathrm{~b}$ & 136 & 11.5 & $\mathrm{a}$ & 194 & 28.7 & $\mathrm{e}$ & 166 & 9.99 & $\mathrm{~cd}$ & 170 & 31.8 & $\mathrm{~d}$ & 162 & 24.9 & c & 13.4 & 0.00 \\
\hline
\end{tabular}


performed by statistical methods may indicate the presence of two different sources for the studied metals. $\mathrm{Cu}$ use is widespread in Pescia in the floriculture industry. $\mathrm{Ni}$ is a micronutrient for plants and its presence may be related to soil fertilization practices (Barker and Pilbeam 2006). On this basis, Group 1 may be classified as an "agriculturerelated group." Group 2 ( $\mathrm{Pb}$ and $\mathrm{Cd})$ can be attributed to traffic emissions (Pulles et al. 2012). Since one of the aims of the research was to identify the possible pollution source, it appears important to consider not only the singular metal itself, but also relationships between different metals and characteristics of the sampling site. By comparing different methods the results are more reliable.

\section{CONCLUSION}

The present investigation was aimed at evaluating the potential of some shrubs to sequester air pollutants and assimilate $\mathrm{CO}_{2}$ from the atmosphere. This information may be relevant for planners and technicians involved in the management of urban green areas.

Elaeagnus $\times$ ebbingei had the highest carbon storage under optimal water availability but revealed its inability to thrive also in drought-prone environments. If water availability is a limiting factor in a site where a planting is designed, other species, such as $P$. $\times$ fraseri, A. unedo, and V.tinus, should be preferred.

A clear discrimination among species regarding their relative capacity for deposition of trace metals was not obtained. However, E. $\times$ ebbingei had the highest whole-plant leaf deposition of all the measured metals, primarily because of its extremely fast growth rate.

The study authors are aware that only a limited number of shrub species were tested in this study of $\mathrm{CO}_{2}$ uptake and air pollution interception potential, and further research is needed to evaluate different species for different climatic areas. However, the results may offer initial insights regarding $\mathrm{CO}_{2}$ assimilation and trace metal deposition potential of widely used shrubs for urban green areas in southern Europe.

\footnotetext{
Acknowledgments. Work was carried out within the project Quantitative Evaluation of Tree and Shrub Species in Order to Mitigate Pollution in the Urban and Periurban Environment, funded by the Ministry for Agricultural Food and Forestry Policies (Mipaaf). We also acknowledge the support of Laboratorio per la Ricerca nel Settore Vivaistico-Ornamentale (LABVIVA) and Uniser Consortium Pistoia.
}

\section{LITERATURE CITED}

Anicic, M., T. Spasic, M. Tomaševic, S. Rajšic, and M. Tasic. 2011. Trace element accumulation and temporal trends in leaves of urban deciduous trees (Aesculus hippocastanum and Tilia spp.). Ecological Indicators 11:824-830.

Araujo, J.A., and A.E. Nel. 2009. Particulate matter and atherosclerosis: rolE of particle size, composition, and oxidative stress. Particle and Fibre Toxicology 6:24.

AUB Landscape Plant Database. 2016. <http://landscapeplants.aub.edu.lb/Plants/GetPDF/635ce76e-da16-43e0-9bbc$88 \mathrm{a} 06 \mathrm{fc} 8199>$

Barker, A.V., and D.J. Pilbeam. 2006. Handbook of Plant Nutrition. Taylor \& Francis, London, UK.

Bealey, W.J., A.G. McDonald, E. Nemitz, R. Donovan, U. Dragosits, T.R. Duffy, and D. Fowler. 2007. Estimating the reduction of urban $\mathrm{PM}_{10}$ concentrations by trees within an environmental information system for planners. Journal of Environmental Management 85:44-58.

Beckett, K.P., P.H. Freer-Smith, and G. Taylor. 2000. Particulate pollution capture by urban trees: Effects of species and windspeed. Global Change Biology 6:995-1003.

Bell, M.L., R.D. Morgenstern, and W. Harrington. 2011. Quantifying the human health benefits of air pollution policies: Review of recent studies and new directions in accountability research. Environmental Science and Policy 14:357-368.

Bombelli, A., and L. Gratani. 2003. Interspecific differences of leaf gas exchange and water relations of three evergreen Mediterranean shrub species. Photosynthetica 41:619-625.

Brikell, C. (Ed.). 2008. RHS A-Z Encyclopedia of Garden Plants. Penguin Books, UK. 1136 pp.

Buccolieri, B., C. Gromke, S. Di Sabatino, and B. Ruck. 2009. Aerodynamic effects of trees on pollutant concentration in street canyons. Science of the Total Environment 407:5247-5256.

Bunzl, K., W. Schimmack, K. Kreutzer, and R. Schierl. 1989. Interception and retention of Chernobyl-derived 134,137Cs and $100 \mathrm{Ru}$ in a spruce stand. The Science of the Total Environment 78:77-87.

Bussotti, F., F. Ferrini, M. Pollastrini, and A. Fini. 2013. The challenge of Mediterranean sclerophyllous vegetation under climate change: From acclimation to adaptation. Environmental and Experimental Botany 103:80-98.

Cavanagh, J.E., P. Zawar-Reza, and G. Wilson. 2009. Spatial attenuation of ambient particulate matter air pollution within an urbanized native forest patch. Urban Forestry \& Urban Greening 8:21-30.

Chaves, M., J. Flexas, and C. Pinheiro. 2008. Photosynthesis under drought and salt stress: Regulation mechanisms from whole plant to cell. Annals of Botany 103:151-160.

Chaves, M., J. Pereira, J. Maroco, M.L. Rodrigues, C.P.P. Ricardo, M.L. Osório, I. Carvalho, T. Faria, and C. Pinheiro. 2002. How plants cope with water stress in the field. Photosynthesis and field growth. Annals of Botany 89:907-916.

Clemson Cooperative Extension. 2015. Red Tip Photinia. <www. clemson.edu/extension/hgic/plants/landscape/shrubs/ hgic1081.html>

Duzgoren-Aydin, N.S., C.S.C. Wong, A. Aydin, Z. Song, M. You, and X.D. Li. 2006. Heavy metal contamination and distribution in the urban environment of Guangzhou, SE China. Environmental Geochemistry and Health 28:375-391. 
Dzierzanowski, K., R. Popek, H. Gawronska, A. Sæbø, and S.W. Gawronski. 2011. Deposition of particulate matter of different size fractions on leaf surfaces and in waxes of urban forest species. International Journal of Phytoremediation 13:1037-1046.

European Trees. 2016. Strawberry Tree (Arbutus). <www.europeantrees.com/strawberry-tree.html>

Fini, A., C. Bellasio, S. Pollastri, M. Tattini, and F. Ferrini. 2013. Water relations, growth, and leaf gas exchange as affected by water stress in Jatropha curcas. Journal of Arid Environments 89:21-29.

Fini, A., F. Ferrini, M. Di Ferdinando, C. Brunetti, C. Giordano, F. Gerini, and M. Tattini. 2014. Acclimation to partial shading or full sunlight determines the performance of container-grown Fraxinus ornus to subsequent drought stress. Urban Forestry \& Urban Greening 13:63-70.

Fini, A., F. Ferrini, P. Frangi, G. Amoroso, and C. Giordano. 2010. Growth, leaf gas exchange, and leaf anatomy of three ornamental shrubs grown under different light intensities. European Journal of Horticultural Science 75(3):111-117.

Fini, A., L. Guidi, F. Ferrini, C. Brunetti, M. Di Ferdinando, S. Biricolti, S. Pollastri, L. Calamai, and M. Tattini. 2012. Drought stress has contrasting effects on antioxidant enzymes and phenylpropanoids biosynthesis in Fraxinus ornus leaves: An excess light stress affair? Journal of Plant Physiology 169:129-139.

Fini, A., P. Frangi, G. Amoroso, R. Piatti, M. Faoro, C. Bellasio, and F. Ferrini. 2011. Effect of controlled inoculation with specific mycorrhizal fungi from the urban environment on growth and physiology of containerized shade tree species growing under different water regimes. Mycorrhiza 21:703-719.

Fowler, D., U. Skiba, E. Nemitz, F. Choubedar, D. Branford, R. Donovan, and P. Rowland. 2003. Measuring aerosol and heavy element deposition on urban woodland and grass using inventories of 210pb and element concentrations in soil. Water, Air \& Soil Pollution 4:483-499.

Freer-Smith, P.H., K.P. Beckett, and G. Taylor. 2005. Deposition velocities to Sorbus aria, Acer campestre, Populus deltoides $\times$ trichocarpa 'Beaupré, Pinus nigra and $\times$ Cupressocyparis leylandii for coarse, fine and ultra-fine particles in the urban environment. Environmental Pollution 133:157-167.

Gebhardt, T., K-H. Häberle, R. Matyssek, C. Schulz, and C. Ammera. 2014. The more, the better? Water relations of Norway spruce stands after progressive thinning. Agricultural and Forest Meteorology 197:235-243.

Grubler, A. 1994. Technology. In: B.M. William and I.I. Turner (Eds.). Changes in Land Use and Land Cover: A Global Perspective. Cambridge University Press, Cambridge. 287 pp.

Herms, D.A., and W.J. Mattson. 1992. The dilemma of plants: To grow or to defend. The Quarterly Review of Biology 67(3):283-335.

Huixia, W., S. Hui, and Li et al. 2013. Seasonal variations in leaf capturing of particulate matter, surface wet ability, and micro morphology in urban tree species. Frontiers of Environmental Science \& Engineering 7(4):579-588.

IPCC. 2013. Summary for Policymakers. In: T.F. Stocker, D. Qin, G.-K. Plattner, M. Tignor, S.K. Allen, J. Boschung, A. Nauels, et al. (Eds.). Climate Change 2013. The Physical Science Basis. Contribution of Working Group I to the Fifth Assessment Report of the Intergovernmental Panel on Climate Change. Cambridge University Press, Cambridge, United Kingdom and New York, New York, U.S.
Jo, H.K., and E.G. McPherson. 1995. Carbon storage and flux in urban residential greenspace. Journal of Environmental Management 45:109-133.

Kalaji, H.M., V. Goltsev, K. Bosa, S. Allakhverdiev, R.J. Strasser, and Govindjee. 2012. Experimental in vivo measurements of light emission in plants: A perspective dedicated to David Walker. Photosynthesis Research 114(2):69-96.

Kozlowski, T.T. 1999. Soil compaction and growth of woody plants. Scandinavian Journal of Forest Research 14:596-619.

Lavid, N., Z. Barkay, and E. Tel-Or. 2001. Accumulation of heavy metals on epidermal glands of waterlily (Nymphaeaceae). Planta 212:313-322.

Litschke, T., and W. Kuttler. 2008. On the reduction of urban particle concentration by vegetation-A review. Meteorologische Zeitschrift 17:229-240.

Lorenzini, G., C. Grassi, C. Nali, A. Petiti, S. Loppi, and L. Tognotti. 2006. Leaves of Pittosporum tobira as indicators of airborne trace element and $\mathrm{PM}_{10}$ distribution in central Italy. Atmospheric Environment 40:4025-4036.

Lu, X., L. Wang, L. Li, Y.K. Lei, L. Huang, and D. Kang. 2010. Multivariate statistical analysis of heavy metals in street dust of Baoji, NW China. Journal of Hazardous Materials 173:744-749.

McCarthy, M.P., M.J. Best, R.A. Betts. 2010. Climate change in cities due to global warming and urban effects. Geophysical Research Letters 37.

McPherson, E.G., and J.R. Simpson. 2003. Potential energy savings in buildings by an urban tree planting program in California. Urban Forestry \& Urban Greening 2:73-86.

Medrano, H., J.M. Escalona, J. Bota, J. Gulias, and J. Flexas. 2002. Regulation of photosynthesis in C3 plants in response to progressive drought: Stomatal conductance as a reference parameter. Annual Botany 89:895-905.

Moreno-Gutiérrez, C., T.E. Dawson, E. Nicolás, and J.I. Querejeta. 2012. Isotopes reveal contrasting water use strategies among coexisting plant species in a Mediterranean ecosystem. New Phytologist 196:489-496.

Mori, J., A. Sæbø, H.M. Hanslin, A. Teani, F. Ferrini, A. Fini, and G. Burchi. 2015b. Accumulation of traffic related air pollutants on leaves of six evergreen shrub species during Mediterranean summer season. Forestry \& Urban Greening 14:264-273.

Mori, J., H.M. Hanslin, G. Burchi, and A. Sæbø. 2015a. Particulate matter and element accumulation on coniferous trees at different distances from a highway. Urban Forestry \& Urban Greening 14:170-177.

Niinemets, U., and J. Peñuelas. 2007. Gardening and urban landscaping: Significant players in global change. Trends in Plant Science 13(2):60-65.

Nowak D.J., E.J. Greenfield, R.E. Hoehn, and E. Lapoint. 2013. Carbon storage and sequestration by trees in urban and community areas of the United States. Environmental Pollution 178:229-236.

Nowak, D.J., and D.E. Crane. 2002. Carbon storage and sequestration by urban trees in the USA. Environmental Pollution 116:381-389.

Nowak, D.J., D.E. Crane, and J.C. Stevens. 2006. Air pollution removal by urban trees and shrubs in the United States. Urban Forestry \& Urban Greening 4:115-123.

Nowak, D.J., J.C. Stevens, S.M. Sisinni, and C.J. Luley. 2002. Effects of urban tree management and species selection on atmospheric carbon dioxide. Journal of Arboriculture 28(3):113-122. 
Nowak, D.J., K.L. Civerolo, S.T. Rao, G. Sistla, C.J. Luley, and D.E. Crane. 2000. A modeling study of the impact of urban trees on ozone. Atmospheric Environment 34:1610-1613.

Oliva, S., and A.J. Espinosa. 2007. Monitoring of heavy elements in topsoils, atmospheric particles and plant leaves to identify possible contamination sources. Microchemical Journal 86:131-139.

O’Meara, M. 1999. Reinventing Cities for People and the Planet, vol. 147. Worldwatch, Washington.

Pant, P., and R.M. Harrison. 2013. Estimation of the contribution of road traffic emissions to particulate matter concentrations from field measurements: A review. Atmospheric Environment 77:78-97.

PBL Netherlands Environmental Assessment Agency. 2013.Trends in global $\mathrm{CO}_{2}$ emissions: 2013 Report.

Penuelas, J., F. Lloret, and R. Montoya. 2001. Severe drought effects on 1365 Mediterranean woody flora. Forest Science 47(2):214-218.

Percival, G.C. 2005. The use of chlorophyll fluorescence to identify chemical and environmental stress in leaf tissue of three oak (Quercus) species. Journal of Arboriculture 31(5):215-227.

Pikridas, M., A. Tasoglou, K. Florou, and S.N. Pandis. 2013. Characterization of the origin of fine particulate matter in a medium size urban area in the Mediterranean. Atmospheric Environment 80:264-274.

Pugh, T.A.M., A.R. MacKenzie, J.D. Whyatt, and C.N. Hewitt. 2012. Effectiveness of green infrastructure for improvement of air quality in urban street canyons. Environmental Science and Technology 46(14):7692-7699.

Pulles, T., H.D. van der Gon, W. Appelman, and M. Verheul. 2012. Emission factors for heavy metals from diesel and petrol used in European vehicles. Atmospheric Environment 61:641-651.

Rosipal, R., and L.J. Trejo. 2001. Kernel Partial Least Squares Regression in Reproducing Kernel Hilbert Space. Journal of Machine Learning Research 2:97-123.

Ruiz-Sanchez, M.C., R. Domingo, A. Torrecillas, and A. PérezPastor. 2000. Water stress preconditioning to improve drought resistance in young apricot plants. Plant Science 156:245-251.

Sæbø, A., R. Popek, B. Nawrot, H.M. Hanslin, H. Gawronska, and S.W. Gawronski. 2012. Plant species differences in particulate matter accumulation on leaf surfaces. Science of the Total Environment 427-428:347-354.

Sakai, W.S. 1974. Scanning electron microscopy and energy dispersive X-ray analysis of chalk-secreting leaf glands of Plumbago capensis. American Journal of Botany 61(1):94-99.

Salmond, J.A., D.E. Williams, G. Laing, S. Kingham, K. Dirks, I. Longley, and G.S. Henshaw. 2013. The influence of vegetation on the horizontal and vertical distribution of pollutants in a street canyon. Science of the Total Environment 443:287-298.

Sammons, J.D., and D. Struve. 2008. Monitoring effective container capacity: A method for reducing over-irrigation in container production systems. Journal of Environmental Horticulture 26(1):19-23.

Semwal, R.L., S. Nautiyal, R.K. Maikhuri, K.S. Rao, and K.G. Saxena. 2013. Growth and carbon stocks of multipurpose tree species plantations in degraded lands in central Himalaya, India. Forest Ecology and Management 310:450-459.

Somogyi, Z., M. Teobaldelli, S. Federici, G. Matteucci, V. Pagliari, G. Grassi, and G. Seufert. 2008. Allometric biomass and carbon factors database. Biogeosciences \& Forestry 1:107-113.
Strasser, R.J., A. Srivastava, and M. Tsimilli-Michael. 2000. The fluorescence transient as a tool to characterize and screen photosynthetic samples. pp. 445-483. In: M. Yunus, U. Pathre, and P. Mohanty (Eds.). Probing Photosynthesis: Mechanisms, Regulation and Adaptation. Taylor \& Francis, London, UK.

Suzuki, K. 2006. Characterization of airborne particulates and associated trace elements deposited on tree bark by ICP-OES, ICP-MS, SEM-EDX, and laser ablation ICP-MS. Atmospheric Environment 40:2626-2634.

Tattini, M., D. Remorini, P. Pinelli, G. Agati, E. Saracini, M. Traversi, and R. Massai. 2006. Morpho-anatomical, physiological, and biochemical adjustments in response to root zone salinity stress and high solar radiation in two Mediterranean evergreen shrubs, Myrtus communis and Pistacia lentiscus. New Phytologist 170:779-794.

Tattini, M., F. Loreto, A. Fini, L. Guidi, C. Brunetti, V. Velikova, A. Gori, and F. Ferrini. 2015. Isoprenoids and phenylpropanoids are part of the antioxidant defense orchestrated daily by drought-stressed Platanus $\times$ acerifolia plants during Mediterranean summers. New Phytologist 207(3):616-626.

Valotto, G., G. Rampazzo, F. Visin, F. Gonella, E. Cattaruzza, A. Glisenti, G. Formenton, and P. Tieppo. 2015. Environmental and traffic-related parameters affecting road dust composition: A multi-technique approach applied to Venice area (Italy). Atmospheric Environment 122:596-608.

West, A.G., T.E. Dawson, E.C. February, G.F. Midgley, W.J. Bond, and T.L. Aston. 2012. Diverse functional responses to drought in a Mediterranean-type shrubland in South Africa. New Phytologist 195:396-407.

Wikipedia. 2016. Stazione meteorologica di Firenze Ximeniano. $<$ https://it.wikipedia.org/wiki/Stazione_meteorologica_di_Firenze_Ximeniano $>$

Jacopo Mori (corresponding author)

Dipartimento di Scienze delle Produzioni Agroalimentari e dell'Ambiente, DiSPAA

Università degli Studi di Firenze

Viale delle Idee 30, 50019

Sesto Fiorentino (FI), Italy

Consiglio per la ricerca in agricoltura e l'analisi delleconomia agraria CREA

Via dei Fiori 8, 51012

Pescia (PT), Italy

jacopo.mori@unifi.it

Alessio Fini

Dipartimento di Scienze delle Produzioni Agroalimentari e dell'Ambiente, DiSPAA

Università degli Studi di Firenze

Viale delle Idee 30, 50019

Sesto Fiorentino (FI), Italy

Gianluca Burchi

Consiglio per la ricerca in agricoltura e l'analisi dell'economia agraria CREA

Via dei Fiori 8, 51012

Pescia (PT), Italy 
Francesco Ferrini

Dipartimento di Scienze delle Produzioni Agroalimentari e dell'Ambiente, DiSPAA

Università degli Studi di Firenze

Viale delle Idee 30, 50019

Sesto Fiorentino (FI), Italy

Résumé. Trois expériences indépendantes ont évalué l'assimilation du $\mathrm{CO}_{2}$ et le dépôt de métaux sur les feuilles de sept espèces d'arbustes à feuilles persistantes (Arbutus unedo L., Elaeagnus $\times$ ebbingei L., Laurus nobilis L., Ligustrum japonicum Thunb., Photinia $\times$ fraseri Dress., Viburnum tinus subsp. lucidum L. et le Viburnum tinus subsp. tinus L.). L'assimilation du $\mathrm{CO}_{2}$ et l'allocation du carbone ont été caractérisées sur des plants en pot sous des conditions optimales de disponibilité en eau en 2011 (Exp. 1) et sous des conditions de sécheresse en 2012 (Exp. 2). Une troisième expérience (Exp. 3) a mesuré le dépôt saisonnier sur les feuilles de Cd, $\mathrm{Cu}, \mathrm{Ni}, \mathrm{Pb}$ et $\mathrm{Zn}$ en 2011 sur des plantes transplantées à proximité d'une route à quatre voies.

Le E. $\times$ ebbingei a démontré la plus élevée assimilation $\mathrm{du} \mathrm{CO}_{2}$ sous les conditions optimales en eau, mais une des plus faibles lors des conditions de sécheresse (Exp. 1,2). A l'inverse, $P . \times$ fraseri avait une assimilation moyenne du $\mathrm{CO}_{2}$, mais celle-ci diminuait moins en période de sécheresse par rapport aux autres espèces. Dans l'expérience $3, E . \times$ ebbingei a démontré le taux de dépôt de métaux le plus élevé, principalement en raison de sa plus grande surface foliaire. Les pluies fréquentes et le pourcentage de $\mathrm{RH}$ réduisaient le dépôt de métaux tandis qu'une plus grande vélocité des vents et la température de l'air augmentaient le dépôt sur les feuilles. Les espèces qui réduisent considérablement l'assimilation $\mathrm{du} \mathrm{CO}_{2}$ sous des conditions de sécheresse ( $V$. tinus subsp. Lucidum, L. japonicum, E. $\times$ ebbingei) ne sont pas recommandées dans les aménagements sujets à la sécheresse, alors que les espèces "mésiques" tolérantes à la sécheresse $(P . \times$ fraseri $)$ devraient être préférées. E. $\times$ ebbingei pourrait être utilisé pour optimiser le dépôt de métaux. Les trois expériences fournissent des indications utiles concernant particulièrement l'assimilation du $\mathrm{CO}_{2}$ (Exp. 1,2) et la capacité de réduction de la pollution atmosphérique (Exp. 3) d'une gamme d'arbustes largement utilisés dans les zones urbaines et la planification du verdissement le long des routes en Europe méridionale.

Zusammenfassung. Drei unabhängige Experimente untersuchten die $\mathrm{CO}_{2}$ Assimilation und Schwermetalbelastung auf den Blättern von 7 immergrünen Sträuchern (Arbutus unedo L., Elaeagnus $\times$ ebbingei L., Laurus nobilis L., Ligustrum japonicum Thunb., Photinia $\times$ fraseri Dress., Viburnum tinus subsp. lucidum L., und Viburnum tinus subsp. tinus L.). Die $\mathrm{CO}_{2}$ Assimilation und die Kohlenstoffeinlagerung wurde in 2011 (Experiment 1) unter optimaler Wasserverfügbarkeit und in 2012 (Exp. 2) unter Trockenheitsbedingungen bei getopften Pflanzen bestimmt. Ein drittes Experiment maß die saisonale Ablagerung von $\mathrm{Cd}, \mathrm{Cu}, \mathrm{Ni}, \mathrm{Pb}$, und $\mathrm{Zn}$ in 2011 auf Blättern von Pflanzen, die in die Nähe einer vierspurigen Straße gepflanzt wurden.

Elaeagnus $\times$ ebbingei zeigte die höchste $\mathrm{CO}_{2}$ Assimilation unter optimalen Wasserbedingungen, aber eine der schlechtesten unter Trockenheitsbedingungen (Exp. 1, 2). Entgegengesetzt hatte $P . \times$ fraseri eine mittlere $\mathrm{CO}_{2}$ Assimilation, aber sie sank während der Trockenheit im Vergleich zu anderen Arten. Im dritten Experiment zeigte E. $\times$ ebbingei die höchste Schwermetalablagerung, hauptsächlich wegen der großen Blattfläche. Großer Regenfall und RH\% reduzierte die die Metalablagerungen, während größere Windbewegung und Lufttemperatur die Blattablagerungen vermehrten. Arten, die ihre $\mathrm{CO}_{2}$ Assimilationen unter Trockenheitsbedingungen drastisch reduzieren ( $V$. tinus subsp. lucidum, L. japonicum, E. $\times$ ebbingei), sind in einer Umgebung mit häufiger Trockenheit nicht zu empfehlen, wo trockenheitstolerante "mesische“ Arten $(P$. $\times$ fraseri)bevorzugt werden sollten. E. $\times$ ebbingei könnte verwendet werden, um die Ablagerung von Metalen zu optimieren. Die drei Experimente liefern nützliche Einsichten über die $\mathrm{CO}_{2}$ Assimilation (Exp. 1,2) und Minderung der Luftverschmutzung (Exp. 3) von flächendeckend verwendeten Sträuchern bei Pflanzungen in urbanen Räumen und Planung von Straßenbegleitgrün in Südeuropa.

Resumen. Tres experimentos independientes evaluaron la asimilación de $\mathrm{CO}_{2}$ y la deposición de metales en la hoja de siete especies de arbustos de hoja perenne (Arbutus unedo L., Elaeagnus $\times$ ebbingei L., Laurus nobilis L., Ligustrum japonicum Thunb., Photinia fraseri $\times$ Dress., Viburnum tinus subsp. Lucidum L. y Viburnum tinus subsp. tinus L.). La asimilación de $\mathrm{CO}_{2}$ y la asignación de carbono se determinaron en 2011 (Exp.1) bajo óptima disponibilidad de agua y en el año 2012 (Exp.2) en condiciones de sequía en las plantas en maceta. Un tercer experimento (Exp.3) midió las deposiciones de hojas estacionales de $\mathrm{Cd}, \mathrm{Cu}, \mathrm{Ni}, \mathrm{Pb}$ y $\mathrm{Zn}$ en 2011 en las plantas trasplantadas en la proximidad de una carretera de cuatro carriles.

E. $\times$ ebbingei mostró la mayor asimilación de $\mathrm{CO}_{2}$ con buena disponibilidad de agua, pero uno de los más bajos en condiciones de sequía (Exp.1,2). A la inversa, $P . \times$ fraseri tuvo asimilación de $\mathrm{CO}_{2}$ intermedio pero disminuyó durante la sequía en comparación con las otras especies. En el Experimento 3, E. × ebbingei mostró la mayor deposición de metales, principalmente debido a su mayor área foliar. Las mayores precipitaciones y la humedad relativa disminuyeron las deposiciones de metal, mientras que una mayor velocidad del viento y la temperatura del aire aumentaron las deposiciones de las hojas. Las especies que redujeron drásticamente la asimilación de $\mathrm{CO}_{2}$ en condiciones de sequía (V. tinus subsp. Lucidum, L. japonicum, E. $\times$ ebbingei) no se recomiendan en entornos propensos a la sequía, donde las especies "mésicas" tolerantes a la sequía (P. x fraseri), deben ser preferidas. E. × ebbingei podría ser utilizado para optimizar la deposición de metales. Los tres experimentos proporcionan información útil sobre todo acerca de la asimilación de $\mathrm{CO}_{2}$ (Exp. 1,2) y la mitigación de la contaminación del aire (Exp. 3) de arbustos ampliamente utilizados para su aplicación en áreas urbanas y la planificación del enverdecimiento a borde de carretera en el sur de Europa. 